adenomas and one (who was taking the oral contraceptive) had a lump caused by fatty tissue and fibrosis. In contrast, prolactin concentrations were not raised in the 20 other premenopausal patients in this series who had fibroadenomas.

Both postmenopausal patients with benign lesions and raised prolactin concentrations had duct ectasia. This histological diagnosis was also made in two other postmenopausal patients whose prolactin concentrations were normal. The one patient with malignant disease and hyperprolactinaemia had an adenocarcinoma.

\section{Discussion}

When the patients with benign and malignant diseases of the breast were divided into groups according to their reproductive status there was a significant difference in the incidence of hyperprolactinaemia between the whole group of premenopausal patients and the whole group of postmenopausal patients. It therefore seems important to consider the reproductive status in any study relating to prolactin measurements in patients with benign and malignant disease of the breast.

Our results do not support the theory of an aetiological relationship between hyperprolactinaemia and breast cancer. Furthermore, analysis of the histological findings in the benign lumps in the patients with and without hyperprolactinaemia does not provide support for an aetiological role of prolactin in this condition either.

Finally, it remains to consider the cause of the hyperprolactinaemia in the seven patients who had levels above $25 \mathrm{ng} / \mathrm{ml}$. Pituitary tumours in these patients were unlikely since skull $x$-ray examinations showed nothing abnormal. None was receiving tranquillizers or other drugs thought to raise prolactin levels. Stress, both physical and psychological (Frantz et al., 1972; Friesen et al., 1972), can raise prolactin concentrations. Possibly the cause of the hyperprolactinaemia in these patients was the psychological stress associated with the fear of surgery for a lump in the breast. These findings emphasize the need for a strictly matched control group in evaluating hormonal profiles in patients with cancer. We suggest that in the case of carcinoma of the breast patients with benign breast disease form the most suitable group for comparison.

S. Franks is supported by a Saltwell Research Fellowship from the Royal College of Physicians. We thank Mr. R. S. Handley for his co-operation and the morbid anatomy department of the Bland Sutton Institute of Pathology, Middlesex Hospital Medical School, for the histological diagnoses.

Requests for reprints should be addressed to S. Franks, Department of Nuclear Medicine, Thorn Institute of Clinical Science, Middlesex Hospital Medical School, London W.1.

\section{References}

Boyns, A. R., et al. (1973). European fournal of Cancer, 9, 99.

Frantz, A. G., Kleinberg, D. L., and Noel, G. L. (1972). Recent Progress in Hormone Research, 28, 527.

Friesen, H., et al. (1972). In Prolactin and Carcinogenesis, ed. by A. R. Boyns and K. Griffiths. Cardiff, Alpha Omega Alpha Press.

Lancet. (1974). 1, 908

Mittra, I., Hayward, J. L., and McNeilly, A. S. (1974). Lancet, 1, 889.

Murray, R. M. L., Mozaffarian, G., and Pearson, O. H. (1972). In Prolactin and Carcinogenesis, ed. A. R. Boyns and K. Griffiths, p. 158. Cardiff, Alpha Omega Alpha Press.

Sinha, Y. N., et al. (1973). Fournal of Clinical Endocrinology and Metabolism, 36, 509 .

\title{
Cutaneous and Ocular Reactions to Practolol
}

\author{
R. H. FELIX, F. A. IVE, M. G. C. DAHL
}

British Medical fournal, 1974, 4, 321-324

\section{Summary}

A total of 21 patients suffering from drug-induced rashes from practolol have been seen over the past two years. The clinical manifestations varied, with the morphological appearances of the rash resembling those of eczema, lupus erythematosus, lichen planus, and a highly characteristic toxic erythematous psoriasiform eruption. Persistent ocular damage was a feature in three cases.

\section{Introduction}

Practolol is a cardioselective beta-blocking agent with intrinsic sympathomimetic activity (Barrett, 1971) used in the treatment of various cardiovascular disorders, particularly angina pectoris and cardiac arrythmias. Early clinical trials with practolol did

\footnotetext{
University Department of Dermatology, Royal Victoria Infirmary, Newcastle upon Tyne NE1 4LP

R. H. FELIX, M.R.C.P., Senior Registrar in Dermatology

M. G. C. DAHL, M.R.C.P., Consultant Dermatologist

Dryburn Hospital, Durham DH1 5TW

F. A. IVE, M.R.C.P., Consultant Dermatologist
}

not reveal any adverse cutaneous reactions (Sandler and Clayton, 1970; George et al., 1970), but the number of patients treated was small and each trial lasted only 12 weeks. In a survey of 2,100 patients who were taking practolol seven patients were found to have developed a micropapular, eczematous, or urticarial rash (Wiseman, 1971). Practolol can also induce a syndrome similar to lupus erythematosus (L.E.) the symptoms of which are fever, polyarthritis, and an erythematous rash, associated with positive results of tests for L.E. cells and antinuclear factor (Raftery and Denman, 1973).

Since the report of a patient with exfoliative dermatitis produced by practolol (Rowland and Stevenson, 1972) an increasing number of patients have been referred to us with a rash which was later found to be caused by this drug. Though some of the patients presented with eczematous or lichenoid rashes most presented with a distinctive psoriasiform eruption which, we feel, produces an easily recognizable diagnostic picture.

\section{Patients}

Twenty-one patients (nine men, 12 women) ranging in age from 45 to 78 years were seen in the skin department. Each patient was taking 100-600 mg of practolol daily (see table) for either angina pectoris or supraventricular tachycardia. Most patients were taking also a combination of other drugs, usually a diuretic, a tranquillizer, and an antihypertensive agent. The duration of treatment with practolol before the onset of the rash 
Details of Patients with Practolol-induced Rash

\begin{tabular}{|c|c|c|c|c|c|c|c|c|}
\hline $\begin{array}{l}\text { Case } \\
\text { No. }\end{array}$ & $\begin{array}{c}\text { Age } \\
\text { (Years) }\end{array}$ & Sex & $\begin{array}{l}\text { Dose of } \\
\text { Practolol } \\
\text { (mg/day) }\end{array}$ & $\begin{array}{c}\text { Duration of } \\
\text { Treatment } \\
\text { before Onset } \\
\text { of Rash } \\
\text { (Months) }\end{array}$ & $\begin{array}{l}\text { Morphological } \\
\text { Appearances } \\
\text { of Rash }\end{array}$ & Associated Clinical Details & $\begin{array}{l}\text { Antinuclear } \\
\text { Factor }\end{array}$ & $\begin{array}{c}\text { Clinical } \\
\text { Challenge } \\
\text { with Practolol }\end{array}$ \\
\hline 1 & 71 & M. & 300 & 2 weeks & Exfoliative & \multirow{3}{*}{$\begin{array}{l}\text { Superficial punctate keratitis, tear } \\
\text { secretion reduced, joint stiffness of } \\
\text { hands }\end{array}$} & - & N.D. \\
\hline 2 & 61 & F. & 300 & 4 & $\begin{array}{l}\text { dermatitis } \\
\text { Eczematous }\end{array}$ & & + & + \\
\hline 3 & 72 & M. & 200 & 1 & Exfoliative & & N.D. & N.D. \\
\hline $\begin{array}{l}4 \\
5\end{array}$ & $\begin{array}{l}63 \\
64\end{array}$ & F. & $\begin{array}{l}200 \\
400\end{array}$ & $\begin{array}{r}4 \\
15\end{array}$ & $\begin{array}{l}\text { Psoriasiform } \\
\text { Psoriasiform }\end{array}$ & \multirow{2}{*}{$\begin{array}{l}\text { Pleural and pericardial effusions, } \\
\text { personal history of psoriasis }\end{array}$} & $\overline{-}$ & $\begin{array}{l}\text { N.D. } \\
\text { N.D. }\end{array}$ \\
\hline $\begin{array}{l}6 \\
7 \\
8\end{array}$ & $\begin{array}{l}67 \\
60 \\
54\end{array}$ & $\begin{array}{l}\text { M. } \\
\text { F. }\end{array}$ & $\begin{array}{l}300 \\
300 \\
400\end{array}$ & $\begin{array}{r}6 \\
15 \\
1\end{array}$ & $\begin{array}{l}\text { Psoriasiform } \\
\text { Psoriasiform } \\
\text { Exfoliative } \\
\text { dermatitis }\end{array}$ & & $\begin{array}{l}- \\
\text { N.D. } \\
+\end{array}$ & $\begin{array}{l}\text { N.D. } \\
+ \\
+\end{array}$ \\
\hline 9 & 63 & F. & 400 & 1 & Lichenoid & \multirow{2}{*}{$\begin{array}{l}\text { Arthropathy of hands, oral lesions } \\
\text { typical of lichen planus } \\
\text { Arthropathy of hands } \\
\text { Personal history of psoriasis }\end{array}$} & + & N.D. \\
\hline $\begin{array}{l}10 \\
11 \\
12 \\
13 \\
14\end{array}$ & $\begin{array}{l}61 \\
59 \\
55 \\
77 \\
45\end{array}$ & $\begin{array}{l}\text { F. } \\
\text { F. } \\
\text { F. } \\
\text { F. }\end{array}$ & $\begin{array}{l}100 \\
300 \\
300 \\
300 \\
300\end{array}$ & $\begin{array}{l}18 \\
18 \\
3 \text { weeks } \\
26 \\
12\end{array}$ & $\begin{array}{l}\text { L.E.-like } \\
\text { Psoriasiform } \\
\text { Psoriasiform } \\
\text { Psoriasiform } \\
\text { Eczematous, }\end{array}$ & & $\begin{array}{l}- \\
\bar{t} \\
\pm\end{array}$ & $\begin{array}{c}+ \\
+ \\
+ \\
\text { N.D. } \\
+\end{array}$ \\
\hline $\begin{array}{l}15 \\
16 \\
17 \\
18 \\
19\end{array}$ & $\begin{array}{l}66 \\
56 \\
45 \\
60 \\
67\end{array}$ & $\begin{array}{l}\text { F. } \\
\text { M. } \\
\text { F. } \\
\text { F. } \\
\text { M. }\end{array}$ & $\begin{array}{r}300 \\
300 \\
100 \\
300 \\
200-600\end{array}$ & $\begin{array}{r}18 \\
9 \\
16 \\
11 \\
21\end{array}$ & $\begin{array}{l}\text { Psoriasiform } \\
\text { Psoriasiform } \\
\text { Psoriasiform } \\
\text { Lichenoid } \\
\text { Psoriasiform }\end{array}$ & \multirow{3}{*}{$\begin{array}{l}\text { Involvement of lips } \\
\text { Bilateral corneal ulcers, bilateral corneal } \\
\text { grafts, partial vision } \\
\text { Tear secretion reduced, bilateral } \\
\text { ectoprion, stomatitis }\end{array}$} & $\begin{array}{l}- \\
\bar{t} \\
\underline{-}\end{array}$ & $\begin{array}{c}+ \\
+ \\
\text { N.D. } \\
+ \\
\text { N.D. }\end{array}$ \\
\hline 20 & 78 & M. & 300 & 1 & Psoriasiform & & - & + \\
\hline 21 & 63 & M. & $200-300$ & 20 & Psoriasiform & & N.D. & + \\
\hline
\end{tabular}

N.D. $=$ Test not done.

varied from two weeks to 26 months with a mean value of 10 months.

\section{Type of Rash}

Fourteen patients presented with a widespread eruption which started with scaling and thickening of the skin of the palms and soles, associated with psoriasis-like plaques over the knees and elbows and over other bony prominences (figs. 1 and 2). The rash later spread to other areas of the limbs and to the trunk and was characterized by erythematous macules with marginated scaling, which in most patients was itchy. Except for one patient (case 12) whose rash was fully developed in three weeks the complete eruption took up to four and a half months to develop. The degree of thickening of palmar skin was variable and because of its insidious onset some patients did not realize that the changes were abnormal.

Three patients presented with an exfoliative dermatitis, and two presented with an eczematous eruption, in one of whom (case 14) the rash cleared after treatment with a topical corti-

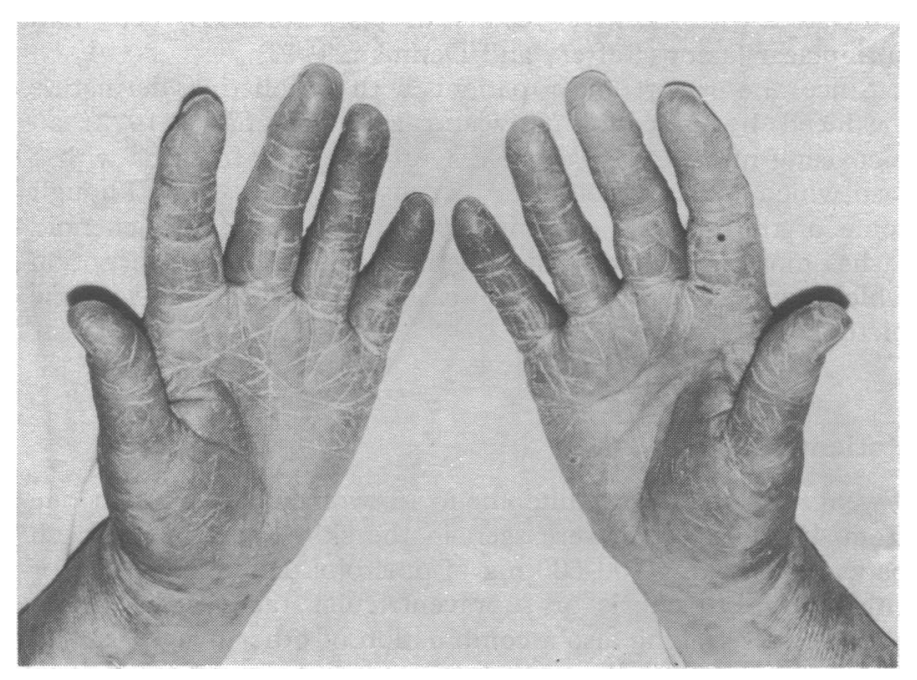

FIG. 1-Hyperkeratosis of palms.

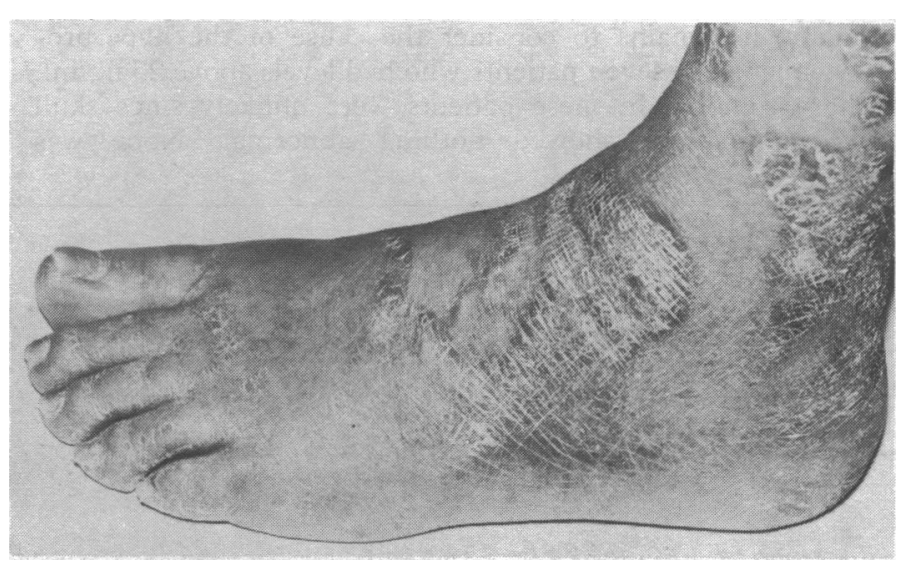

FIG. 2-Psoriasiform rash on left foot.

costeroid in spite of continuing treatment with practolol. One month after topical treatment was stopped the rash began to return and after about four months the patient had developed a widespread guttate psoriasiform rash, with thickening and fissuring of the skin on both palms.

Two patients (cases 9 and 18) developed lichenoid eruptions with dusky red, flat-topped, itchy lesions distributed mainly over the forearms and distal parts of both legs. The patient in case 9 also had lesions similar to those of lichen planus in the mouth.

One patient (case 10) developed an erythematous scaly eruption on the backs of both hands which later spread to the forearms and legs; in appearance it was similar to the rash seen in lupus erythematosus.

Three patients complained of soreness of both eyes (fig. 3). One patient (case 2) was found to have a superficial punctate keratitis which initially responded to regular application of artificial tears. Two years later she was still complaining of sore eyes, and tear secretion was found to be reduced bilaterally. One of the three patients (case 19) subsequently developed bilateral corneal ulcers, which required bilateral corneal grafts.

Three patients complained of arthralgia with joint swelling in the hands. The arthralgia improved promptly once practolol was stopped, and joint swelling disappeared within four to six weeks. 


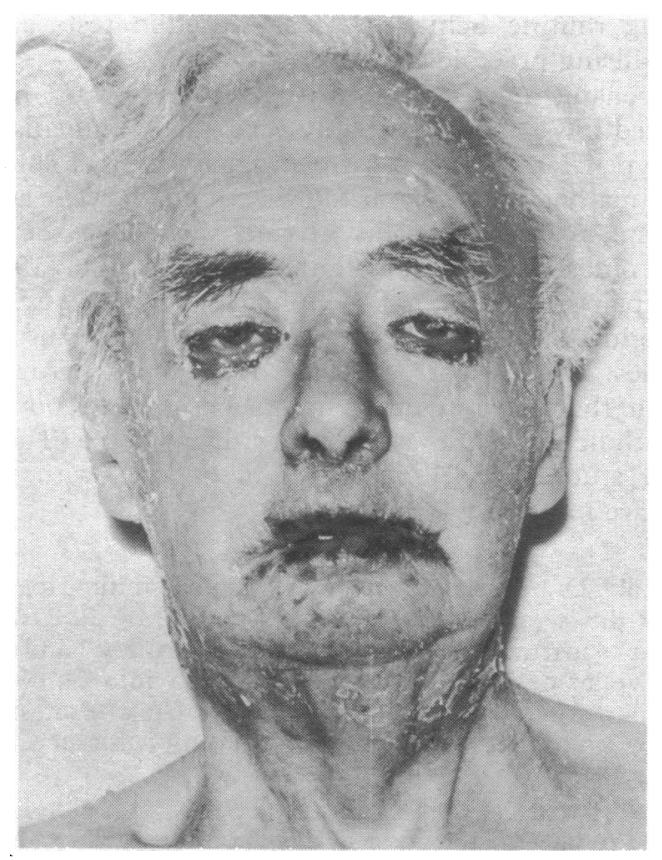

FIG. 3-Case 20. Bilateral ectropion and stomatitis.

One patient with a history of psoriasis (case 5) developed a generalized psoriasiform eruption three months after developing thickened skin on the palms and soles. He had also a history of angina pectoris and was taking practolol $400 \mathrm{mg}$ daily and clofibrate $1 \mathrm{~g}$ daily. He later complained of breathlessness and chest pain and was admitted as an emergency to hospital, where he was found to have fever, an acute pericarditis associated with a large pleural effusion, and cardiomegaly. At this stage practolol was stopped. Apart from a raised erythrocyte sedimentation rate the results of investigations, including bronchoscopy, failed to support a diagnosis of a bronchial neoplasm, and after a short period of monitoring on an intensive treatment unit the patient's general condition and rash gradually improved. He was discharged home six weeks later and after six months he had made a complete recovery.

\section{Treatment}

The severity of the rash or of the cardiovascular disorder determined whether a patient was treated as an inpatient or outpatient. Nine patients required hospital admission. As an alternative beta-blocking agent oxyprenolol was prescribed in 10 patients and propranolol in four. No recurrence was noted on the revised regimen. Practolol was stopped in all cases and the rash was treated with a topical corticosteroid though none of the patients were given systemic corticosteroid therapy. The skin recovered completely within three to six weeks.

\section{Results}

SKIN TESTS

When the rash had completely cleared for at least one month patch tests using either the pure powder of practolol made up in yellow soft paraffin at concentraiions of $50 \%$ and $10 \%$ or the injectable form $(2 \mathrm{mg} / \mathrm{ml})$ made up in propylene glycol at concentrations of $50 \%$ and $10 \%$ were carried out in 14 of the patients, one of whom gave a positive result. Intradermal tests, in which practolol $0.05 \mathrm{ml}$. $(10 \mu \mathrm{g} / \mathrm{ml})$ was injected into the forearm, were performed on 13 of the patients, and a reaction was seen in three. Intradermal test results in control subjects were negative. In one patient the response to the intradermal test remained positive for 24 hours (case 2). Further details of this patient have been reported previously (Felix and Comaish, 1974).

\section{ORAL CHALIENGE}

Twelve of the patients agreed to oral challenge with practolol. They were told to take one tablet $(100 \mathrm{mg})$ every 12 hours and to report immediately if any reaction developed. Nine patients reported after 36 hours, one (case 20) after four days, and one (case 14) after five days. Each patient first noticed itching followed by the appearance of an erythematous macular eruption. The patient in case 14 was rechallenged one month later and developed itching with a widespread erythematous macular eruption four hours after taking one tablet of practolol.

One patient (case 11) developed an erythematous scaly eruption confined largely to the elbows and knees four weeks after the start of the challenge. The distribution of the rash was identical to the original psoriasiform eruption. One of the patients (case 18) who developed a lichenoid eruption was challenged and complained of an itchy erythematous rash which was confined precisely to the sites of the original rash. No adverse systemic effects developed in any of these patients.

\section{LABORATORY INVESTIGATIONS}

Antinuclear factor was present in the serum of five of the 18 patients tested, and L.E. cells were found in one patient. In one patient the antinuclear factor was present for 16 months after practolol was stopped, while in the remaining four patients it persisted for four to six weeks. Serum samples taken from the patients positive for antinuclear factor were estimated for anti-DNA antibodies and the results were found to be within normal limits.

\section{HISTOLOGY AND IMMUNOFLUORESCENCE}

Histological specimens were obtained from 10 patients. All sections stained with haematoxylin and eosin showed essentially similar and diagnostic changes though they varied in degree depending on whether the clinical picture was psoriasiform, eczematous, or lichenoid.

The most striking changes were seen in those sections simulating lichen planus where there was atrophy of the epidermis with the production of large numbers of colloid bodies representing dead epidermal cells migrating through the epidermis and settling in the outer horny layer. In the other clinical groups this feature was less florid, but in all cases, regardless of clinical appearance, periodic-acid Schiff stains showed marked patchy swelling and disruption of the basement membrane as seen in cases of lichen planus or lupus erythematosus.

Skin biopsy specimens from eight patients were examined by immunofluorescence for the presence of bound immunoglobulins (IgG, IgM, and IgA) and complement (C3). Very fine granular deposits of IgG, IgM, and C3 were present along the dermoepidermal junction in six patients. The immunofluorescence findings resembled in some ways those found in L.E., but the granular pattern was much finer than is usually seen in this condition. A more detailed description of the histological and immunofluorescent patterns will be the subject of a further report.

\section{Discussion}

Identification of the culprit in suspected drug reactions is often handicapped by the absence of a specific in-vitro test. Patch and intradermal testing were of little value in these patients, and oral challenge, which was considered justifiable, provided proof 
of the association in all 12 patients tested. Withdrawal of the drug produced a rapid resolution of skin problems in all patients, and no recurrence was seen on instituting alternative betablockade therapy.

Zacharias (1972) reported that 16 out of 156 patients developed slowly progressive chronic skin reactions which appeared to be of a mixed eczematous and psoriatic nature. In our 21 patients 14 presented with a distinctive picture of a psoriasiform eruption which was most marked over bony prominences, invariably preceded by hyperkeratotic changes on the palms, soles, and sides of the fingers, and followed by an erythematous scaling, marginated rash involving other areas of the body. The full clinical picture tended to develop over several months. In only two of our patients was there a previous history of psoriasis, and we have no evidence that pre-existing psoriasis is aggravated by practolol. Despite the psoriasiform appearance of the eruption the histology never suggested true psoriasis. The slow evolution of this psoriasiform type of rash is in marked contrast to the acuteness of the lichenoid, L.E.-like, and erythrodermatous reactions.

Five of our patients $(24 \%)$ had antinuclear factor in the serum whereas Raftery (1972) reported an incidence of 3\%-4\% in all patients on practolol. There were two patients with arthropathy who were positive for antinuclear factor, while six patients showed some histological features compatible with a diagnosis of lupus erythematosus. The one patient with polyserositis was negative for antinuclear factor and L.E. cell phenomenon were absent. In four patients with a positive response antinuclear factor persisted for two to three months after practolol had been stopped, which is in keeping with a diagnosis of drug-induced systemic lupus erythematosus (S.L.E.) (Bodman et al., 1967; Alarcon-Segovia, 1969). In one patient the antinuclear factor persisted for 16 months. Antibodies to native DNA were not found in the patients who were positive for antinuclear factor, confirming the findings of Hughes (1971) that drug-induced S.L.E. can be distinguished from true S.L.E. by the absence of antibodies to native DNA.

Three of our patients had sore dry eyes as reported by Wright (1974), and tear secretion was found to be diminished in two on formal testing. The third patient developed bilateral corneal ulcers. In all three patients eye symptoms were still present at the time of writing despite drug withdrawal, and the ophthalmological problems may well prove to be the most serious aspect of this drug-induced syndrome. A strong case can be made for performing routine Schirmer's tear secretion tests at regular intervals during practolol therapy.

The mechanism whereby this drug reaction occurs has yet to be clarified. We have probably excluded immediate- and delayed-type allergies. It is possible that since practolol acts as a partial sympathomimetic agonist it will stimulate cyclic adenosine monophosphate activity. This in turn may have some direct effect on epidermal cells or, as Raftery and Denman (1973) suggested, impair the activity of T-lymphocyte populations, resulting in the production of strains of lymphocytes with autoimmune propensities. It is of interest that a histological picture closely resembling that seen in our patients has been reported in a patient with lichen planus associated with thymoma (Tan, 1974).

Further studies of cell dynamics in patients with practolol reactions are in progress.

We thank Dr. Graham Hughes, Hammersmith Hospital, for examining the sera for anti-DNA antibody, Mr. P. Drummond, ophthalmic department, Royal Victoria Infirmary, and Mr. D. Wilkins, Welloome Laboratories for Research into Skin Diseases, for the immunofluorescent studies. We thank Professor Sam Shuster for his advice, and Dr. C. J. Stevenson for permission to reproduce (fig. 3 ).

Requests for reprints should be sent to Dr. R. H. Felix, University Department of Dermatology, Royal Victoria Infirmary, Newcastle upon Tyne.

\section{References}

Alarcon-Segovia, D. (1969). Mayo Clinical Proceedings, 44, 664. Barrett, A. M. (1971). Postgraduate Medical fournal, January 1971 Supple-

modman, S. F., Hoffman, J. J., and Condemi, J. J. (1967). Arthritis and Rheumatism, 10, 269.

George, C. F., Nagle, R. E., and Pentecost, B. L. (1970). British Medical George, C. F., Nag.

Felix, R. H., and Comaish, J. S. (1974). Lancet, 1, 1017.

Hughes, G. R. (1971). Lancet, 2, 861.

Raftery, E. B. (1972). In New Perspectives in Beta-blockade International Symposium, p. 239. Denmark. Ciba Laboratories.

Raftery, E. B. and Denman, A. M. (1973). British Medical fournal, 2, 452. Rowland, M. G. M., and Stevenson, C. J. (1972). Lancet, 1, 1130.

Sandler, G., and Clayton, G. A. (1970). British Medical fournal, 2, 399.

Tan, R. S. H. (1974). Proceedings of the Royal Society of Medicine, 67, 196. Wiseman, R. A. (1971). Postgraduate Medical fournal 47, supplement No. 2. p. 68 .

Wright, P. (1972). British Medical fournal, 2, 560.

Zacharias, F. J. (1972). In New Perspectives in Beta-blockade International Symposium, p. 238. Denmark. Ciba Laboratories.

\section{Haemoglobin Belfast 15 (A12) Tryptophan $\rightarrow$ Arginine: A New Unstable Haemoglobin Variant}

\section{COTTON KENNEDY, GILLIAN BLUNDELL,}

British Medical fournal, 1974, 4, 324-326

\section{Summary}

A new unstable haemoglobin, $\alpha_{2} \beta_{2} 15$ Trp $\rightarrow$ Arg (Hb Belfast), with increased oxygen affinity has been found during the routine investigation of a long-stay psychiatric

Belfast City Hospital, Belfast BT9 7AB

C. COTTON KENNEDY, D.M., F.R.C.PATH., Consultant Clinical Patholo-

gist, Department of Haematology
GILLIAN BLUNDELL, M.B., M.R.C.PATH., Senior Registrar, Department of Clinical Chemistry

M.R.C. Abnormal Haemoglobin Unit, University Department of Biochemistry, Addenbrooke's Hospital, Cambridge CB2 2QR

P. A. LORKIN, B.A., Member of Scientific Staff

A. LANG, PH.D., Member of Scientific Staff

H. LEHMANN, M.D., SC.D., F.R.S., Honorary Director

\section{P. A. LORKIN, A. LANG, H. LEHMANN}

patient. It seemed to cause little haematological disorder. The reticulocytes synthesized normal and abnormal $\beta$-chains at the same rate but in the circulating blood Hb Belfast amounted to only $27.5 \%$ of the total haemoglobin.

\section{Introduction}

About 40 unstable haemoglobins have now been described (Lehmann, 1974). A few were discovered by chance, and we report such a haemoglobin found in the course of routine investigation of a long-stay psychiatric patient.

\section{Case Report}

A 42-year-old Caucasian man had for the past 15 years been confined to hospital with paranoid schizophrenia. His history included appendi- 